\title{
Adhesion of cultured human endothelial cells onto methacrylate polymers with varying surface wettability and charge
}

\author{
P.B. van Wachem, A.H. Hogt, T. Beugeling, J. Feijen, A. Bantjes, J.P. Detmers and \\ W.G. van Aken \\ Department of Chemical Technology, Twente University of Technology, PO Box 217, 7500 AE Enschede, The Netherlands \\ (Received 15 December 1986; revised 26 February 1987)
}

\begin{abstract}
The adhesion of human endothalial cells (HEC) onto a series of well-characterized methacrylate polymer surfaces with varying wettabilities and surface charges was studied either in serum-containing (CMS) or in serum-free (CM) culture medium. HEC adhesion in CMS onto (co)polymers* of hydroxyethyl methacrylate (HEMA) and methyl methacrylate (MMA) was found to be optimal on the moderately wettable copolymer (mol ratio 25 HEMA/75 MMA). Positively-charged copolymers of HEMA or MMA with trimethylaminoethyl methacrylate- $\mathrm{HCl}$ salt (TMAEMA-CI), both with mol ratios of $85 / 15$ and a negatively-charged copolymer of MMA with methacrylic acid (MAA), mol ratio 85/15, showed high numbers of adhering HEC.

In CM, HEC adhered onto the three charged copolymers mentioned ahove, but neither onto the copolymer of HEMA and MAA (mol ratio 85/15) nor onto the HEMA/MMA co- and homopolymers. Complete cell spreading in CM was only observed on the positively-charged copolymers.
\end{abstract}

Keywords: Polymers, cells thuman endothelial), cellular adhesion, methacrylate (colpolymers, surface wettability, surface charge

The development of endothelium-lined vascular grafts requires a thorough study of the effects of polymer surface properties on the adhesion and growth of cultured human endothelial cells (HEC).

The adhesion and proliferation of different types of mammalian cells on(to) various surfaces depends on polymer surface characteristics like (water) wettability and charge ${ }^{1,2}$. A range of methacrylate polymers and copolymers have been used to study the adhesion of blood platelets, fibroblasts and epithelial cells as a function of surface wettability ${ }^{3-5}$. In general, a decreased adhesion of platelets and fibroblasts was observed on more hydrophilic copolymers. Adhesion of fibroblasts onto methacrylate (co)polymers also depends on the surface charge: hydrophilic copolymers with a positive surface charge appear to promote cellular adhesion ${ }^{6}$.

We have previously demonstrated that human endothelial cells (HEC) adhere (and spread) preferably onto moderately wettable polymers such as tissue culture polystyrene (TCPS), a glow discharge-treated polystyrene with a water contact angle of $35^{\circ}$. The adhesion of HEC onto TCPS in serum-containing culture medium is strongly

*(co)polymers includes copolymers as well as homopolymers influenced by the presence of serum proteins at the substrate surface. Initial adhesion of HEC is promoted by preadsorption of surfaces with plasma fibronectin ${ }^{8}$. In the absence of serum the deposition of protein(s) by the cells onto substrates may play an important role ${ }^{9}$.

In this paper the results of a study on the adhesion of HEC onto a series of well-characterized methacrylate (co)polymer surfaces ${ }^{10,11}$ are presented. The adhesion of HEC onto these polymers is related to the surface wettability and charge. The role of serum in the adhesion of HEC onto the polymer surfaces is evaluated.

\section{MATERIALS AND METHODS}

\section{Materials}

The synthesis of methacrylate (co)polymers has been previously described ${ }^{12-15}$. The methacrylate (co)polymers used in this study were: poly(hydroxyethyl methacrylate) (PHEMA), poly(methyl methacrylate) (PMMA), copolymers of HEMA and MMA (mol ratios 75/25,50/50 and 25/75) and copolymers of HEMA or MMA and $15 \mathrm{~mol} \%$ methacrylic acid (MAA) or 15 mol\% trimethylaminoethyl methacrylate 
(TMAEMA- $\mathrm{HCl}$ salt). The latter surfaces are further referred to as 85 HEMA 15 MAA, 85 MAA 15 MAA, 85 HEMA 15 TMAEMA-Cl and 85 MMA 15 TMAEMA-Cl. All polymers were synthesized by radical polymerization using 2,2'azobis-(methyl isobutyrate) as initiator ${ }^{10,12,13,16,17}$.

The methacrylate (co)polymers were coated on glass slides or silanized glass slides by uniform dipping of the slides in polymer solutions ${ }^{10,11}$. One mol\% of hexamethylene diisocyanate (HMDIC) was used as a postcrosslinking agent for PHEMA, 85 HEMA 15 MAA and 85 HEMA 15 TMAEMA-Cl. Coatings were prepared under clean-room conditions and were not sterilized before use in the cell adhesion experiments.

The material surfaces were characterized by receding water contact angles, as measured by the Wilhelmy plate technique $e^{10,18}$, and by zeta-potentials calculated from streaming potential-measurements using a buffer containing $0.01 \mathrm{M} \mathrm{KCl}$ and $1 \mathrm{~mm}$ phosphate $(\mathrm{pH} \mathrm{7.4})^{18.19}$. The results are presented in Tab/e 1.

\section{Cell culture}

Endothelial cells were isolated from human umbilical cord veins according to the method of Jaffe et al. ${ }^{20}$ with some modifications ${ }^{21}$. The cells were routinely cultured in tissue culture polystyrene (TCPS) flasks (Corning, New York, USA) precoated with a partially purified human plasma fibronectin, $\left(\mathrm{Fn}^{\mathrm{c}}, 2 \mathrm{mg} / \mathrm{ml} ; \mathrm{Fn}^{\mathrm{c}}\right.$ is a coproduct obtained during purification of human Factor VIII, Central Laboratory of the Netherlands Red Cross Blood Transfusion Service, Amsterdam). The serum-containing culture medium (CMS) consisted of complete medium (CM), which is an equal mixture of medium M199 and medium RPMI1640 (both from Gibco Biocult Co., Paisley, UK), to which $2 \mathrm{mM}$ of L-glutamine (Merck, Darmstadt, FRG), $100 \mathrm{U} / \mathrm{ml}$ of penicillin, $100 \mu \mathrm{g} / \mathrm{ml}$ of streptomycin (both from Flow Lab., Irvine, UK) and $2.5 \mu \mathrm{g} / \mathrm{ml}$ of fungizone (Gibco) were added. CM was supplemented with $20 \%$ human serum (pool of 20 healthy male donors) in order to obtain CMS.

Experiments were carried out with endothelial cells harvested after the second or third passage when the cells had reached confluency.

\section{Cell adhesion}

For cell adhesion experiments, methacrylate (co)polymercoated glass slides were mounted into a modified 'Bionique' growth chamber (Corning, New York, USA: test surface area of $5 \mathrm{~cm}^{2}$ ), as described earlier ${ }^{7}$. Endothelial cells were

Table 1 Receding contact angles and zeta-potentials of methacrylate (co)polymers*

\begin{tabular}{lcl}
\hline (Co)polymer (mol ratios) & $\begin{array}{l}\text { Contact angle } \\
\text { (degrees) }\end{array}$ & $\begin{array}{l}\text { Zeta-potential } \\
\text { (mV) }\end{array}$ \\
\hline PHEMA & 4 & -8 \\
75 HEMA/25 MMA & 8 & ND \\
50 HEMA 50 MMA & 26 & ND \\
25 HEMA 75 MMA & 39 & ND \\
PMMA & 57 & -29 \\
85 HEMA 15 MAA & 3 & -24 \\
85 HEMA 15TMAEMA-Cl & 2 & +5 \\
85 MMA 15 MAA & 4 & -41 \\
85 MMA 15 TMAEMA-Cl & 1 & +4
\end{tabular}

* Receding contact angles measured by the Wilhelmy plate method. For abbreviations, see Materials and Methods. No, Not determined. harvested after trypsin treatment $(0.05 \%$ trypsin/0.02\% EDTA, Gibco). Residual trypsin was inactivated by addition of CMS.

Three series of adhesion experiments (a-c) were carried out. For each series endothelial cells from one umbilical cord vein were used. The following surfaces were studied: (a) PHEMA, PMMA and HEMA MMA copolymers: HEC were seeded in the presence of CMS, (b) PHEMA, PMMA and copolymers with MMA or TMAEMA-Cl; HEC were seeded in the presence of CMS, and (c) all surfaces of (a) and (b); the cells were seeded in the presence of $\mathrm{CM}$. The results of HEC adhesion onto the (co)polymers of each series were compared to those of the adhesion onto uncoated TCPS (Costar, Cambridge, MA, USA; 6-well tissue culture clusters with a test surface area of $10 \mathrm{~cm}^{2}$ per well).

Cell adhesion onto surfaces in CMS ( $a$ and $b$ ) was determined at various time intervals $(30 \mathrm{~min}, 1,2$ and $6 \mathrm{~h}$ after seeding of $4 \times 10^{4}$ cells $/ \mathrm{cm}^{2}$. After the appropriate incubation time, the test surfaces were washed twice with phosphate-buffered saline (PBS, obtained from NPBI, Emmer-Compascuum, The Netherlands). Harvesting of the adherent cells for cell counting was carried out by trypsinization (0.05\% trypsin). In the case of the positively-charged copolymers a trypsin concentration of $0.5 \%$ was used. The collected cells were counted using a haemocytometer. The adhesion experiments of series $c$ were carried out in serumfree medium. After cell harvesting trypsin was inactivated with CMS. $\mathrm{HEC}$ were washed three times with $\mathrm{CM}$ to remove the serum and then seeded in $\mathrm{CM}$. The adhesion of $\mathrm{HEC}$ onto surfaces was determined $1 \mathrm{~h}$ after cell seeding. In this series the adherent cells could not be detached from methacrylate (co)polymer surfaces by trypsinization. Therefore cell adhesion was measured by direct photography. After the adherent cells had been washed twice with PBS, photographs of nine different areas at distinct positions on each test surface mounted into a test chamber were taken. From these photographs the numbers of adherent cells were calculated. However, due to the configuration of the test chamber more seeded cells sediment on the central part of the test surface. Therefore the number of cells calculated by photography did not adequately represent the cell density over the entire test surface area. To overcome this problem, a modified polyester surface (tissue culture polyethylene terephthalate, TCPETP, Falcon film-lined dish, Becton Dickinson, Oxnard CA, USA) was used to correlate calculations made by direct photography and measurements made by trypsinization, since this material could be mounted into the test chambers and cells detached from this surface at a trypsin concentration of $0.5 \%$. In this way, a ratio was obtained to convert cell adhesion numbers on TCPETP measured by photography to numbers of cells which were actually detached from this surface by trypsin. This ratio was then used to determine the numbers of cells adhering to methacrylate (co)polymers.

For all series, average numbers of adhering cells per surface were calculated from data obtained from three independent adhesion experiments per material. Adhesion data for different surfaces are then expressed as percentages of the numbers of cells found on TCPS precoated with $\mathrm{Fn}^{\mathrm{c}}$. For each type of surface in the series $\mathrm{a}, \mathrm{b}$ and $\mathrm{c}$ two experiments were carried out to investigate cell proliferation. For series c, the cells were kept in CM for $24 \mathrm{~h}$ and then CM was replaced by CMS. For all the series CMS was refreshed daily. The volume of CMS in the test chamber was adjusted so that the ratio between this volume (in $\mathrm{ml}$ ) and the test surface area (in $\mathrm{cm}^{2}$ ) of the polymer was 0.2 . Cell proliferation was monitored up to $8 \mathrm{~d}$ using light microscopy. 


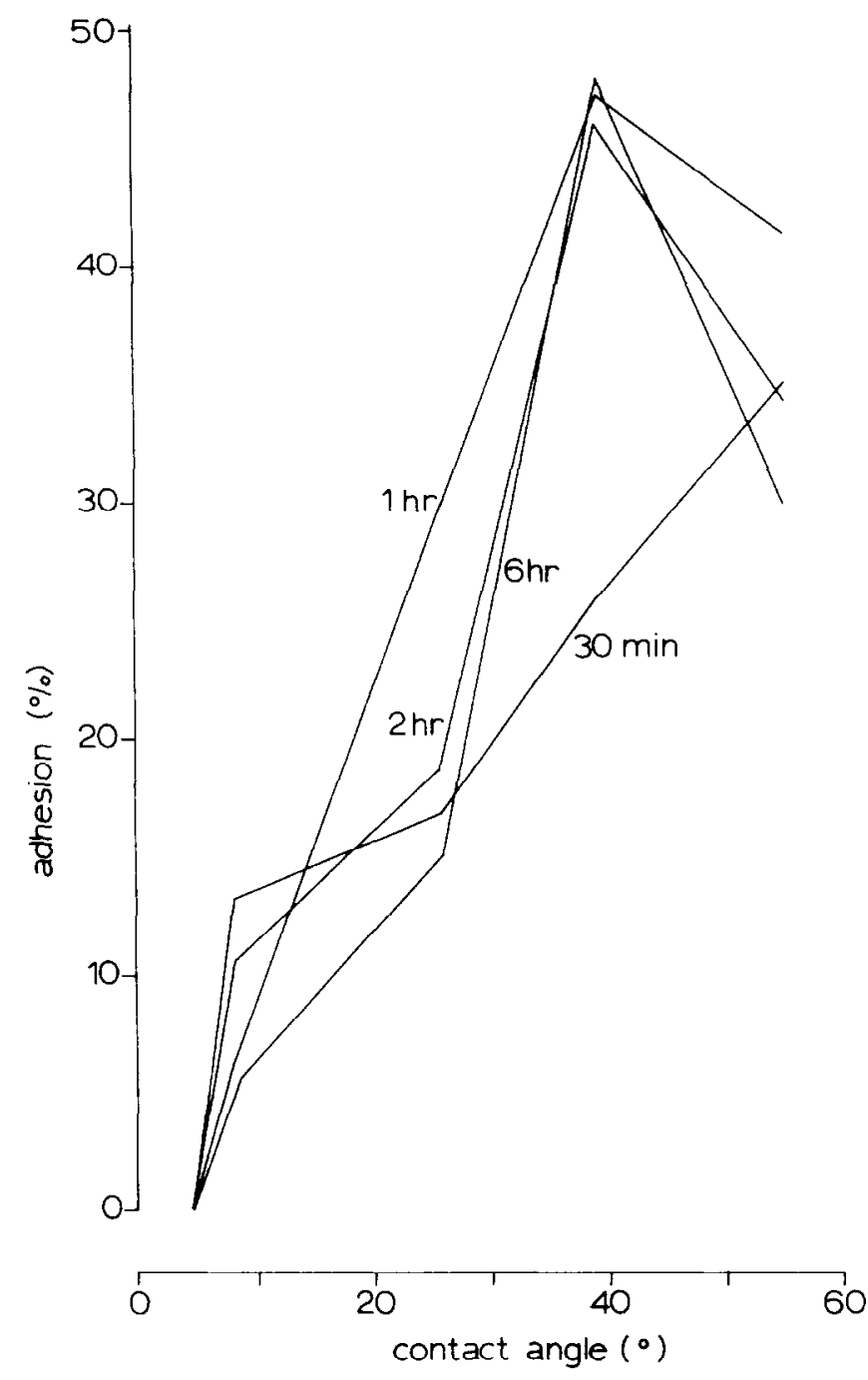

Figure 1 Adhesion of HEC in CMS as a function of methacrylate (co)polymer receding contact angle: $4 \times 10^{4} \mathrm{cells} / \mathrm{cm}^{2}$ in CMS were seeded onto the test surfaces. Cell counts at 30 min, 1, 2 and $6 \mathrm{~h}$ are expressed as percentages of numbers of cells adhering to TCPS precoated with Fn'. Receding contact angles of surfaces were measured by the Wilhelmy plate method.

\section{RESULTS}

\section{Effect of surface wettability}

HEMA/MMA copolymers show increasing receding water contact angles with decreasing HEMA content.

The adhesion of HEC in CMS onto the methacrylate (co)polymer surfaces of series a was determined at different time intervals after seeding (see Figure 1 and Tab/e 2). At $30 \mathrm{~min}$, PMMA showed a cell adhesion of $35 \%$ relative to

Table 2 Adhesion of HEC onto HEMAVMMA (colpolymers and TCPS in the presence of serum*

\begin{tabular}{lllll}
\hline (Co)polymer & $30 \mathrm{~min}$ & $1 \mathrm{~h}$ & $2 \mathrm{~h}$ & $6 \mathrm{~h}$ \\
\hline PHEMA & 0 & 0 & 0 & 0 \\
75 HEMAV25 MMA & $13.3 \pm 4.5$ & $6.6 \pm 5.5$ & $10.6 \pm 5.4$ & $5.7^{\mathrm{a}}$ \\
50 HEMA 50 MMA $16.9 \pm 6.1$ & $29.8 \pm 14.8$ & $18.8 \pm 7.9$ & $15.0 \pm 0.6$ \\
25 HEMAV75 MMA & $25.9 \pm 10.4$ & $47.4 \pm 7.6$ & $46.2 \pm 3.8$ & $47.7 \pm 4.0$ \\
PMMA & $35.3 \pm 2.7$ & $41.4 \pm 7.0$ & $34.6 \pm 3.8$ & $30.0 \pm 5.8$ \\
TCPS & $66.4 \pm 3.4$ & $91.7 \pm 8.4$ & $\mathbf{8 7 . 0 \pm 3 . 4}$ & $100.0^{\mathrm{a}}$ \\
\hline
\end{tabular}

* $4 \times 10^{4}$ cells $/ \mathrm{cm}^{2}$ in CMS were seeded onto the test surfaces. Cell counts ( $\pm \mathrm{sD}$ ) at $30 \mathrm{~min}, 1,2$ and $6 \mathrm{~h}$ are expressed as percentages of numbers of cells adhering to TCPS precoated with $\mathrm{Fn}^{\mathrm{c}}$. For abbreviations, see Materials and Methods.

${ }^{a}$ Data obtained from one adhesion experiment. that on TCPS precoated with $\mathrm{Fn}^{\mathrm{c}}$. Upon further incubation this percentage did not change significantly.

At $1 \mathrm{~h}$ and after further incubation, the moderately wettable copolymer 25 HEMA 75 MMA (contact angle $=39^{\circ}$ ) exhibited the highest percentage of adhering cells. Light microscopy revealed that cell spreading within this series was most extensive on this copolymer. Substantially lower cell adhesion percentages were found with the (more) hydrophilic (co)polymers. No cell adhesion was found on PHEMA. In time, uncoated TCPS showed cell adhesion percentages up to $100 \%$. The cell spreading observed on uncoated TCPS was as complete as on TCPS precoated with $\mathrm{Fn}^{\mathrm{c}}$. Proliferation of HEC was only observed on $25 \mathrm{HEMA}$ 75 MMA (at $2 \mathrm{~d}$ ) and PMMA (at $4 \mathrm{~d}$ ) (not shown). Proliferation of HEC on these surfaces started from cell clusters which initially exhibited a spiderlike morphology but soon changed into a spread structure. In time single adherent cells on these surfaces died and detached from the surface. On uncoated TCPS, HEC proliferated as previously reported?

\section{Effect of surface charge}

Another series of experiments (b) was performed to investigate the influence of surface charge of methacrylate (co)polymers on the adhesion of HEC in the presence of CMS. The MMA and HEMA polymers had a net negative zeta-potential (Table 1). The incorporation of TMAEMA-Cl in HEMA or MMA polymers resulted in slightly positivelycharged surfaces, whereas the combination of MAA with either HEMA or MMA yielded copolymers with increased negative zeta-potentials as compared to the homopolymers.

Two hours after cell seeding, about $65 \%$ of the number of HEC adhering onto the reference surface was found upon the negatively-and positively-charged MMA copolymers (85 MAA 15 MAA and 85 MMA 15 TMAEMA-Cl), while approx. $80 \%$ of this number adhered onto the positivelycharged HEMA copolymer (85 HEMA 15 TMAEMA-Cl) (Figure 2). HEC did not adhere onto PHEMA nor onto the negatively-charged 85 HEMA 15 MAA. In series $b$, higher levels of adhering HEC were observed upon PMMA as found in series a (Table 2). This may be explained by the fact that for each series, cells from different umbilical cord veins were used. On PMMA, again incomplete cell spreading was observed. The most pronounced cell spreading was seen on the positively-charged copolymers. Cells only proliferated on the negatively-and positively-charged MMA copolymers and on the positively-charged HEMA copolymer.

\section{Effect of culture medium}

The adhesion of HEC onto the (co)polymers after $1 \mathrm{~h}$ was also investigated using serum-free medium (series c; Table 3). HEC adhesion onto the positively-charged surfaces (85 HEMA 15 TMAEMA-Cl) and (85 MMA/15 TMAEMACl) was about the same when compared to the adhesion found on uncoated TCPS. HEC did not adhere to any of the other surfaces, except for the $85 \mathrm{MMA} / 5 \mathrm{MMA} \mathrm{co}^{-}$ polymer ( $8.6 \%$ adhesion). After $1 \mathrm{~h}$, spreading of HEC upon the positively-charged MMA copolymer was as complete as the spreading observed upon TCPS precoated with $\mathrm{Fn}^{\circ}$. On the positively-charged HEMA copolymer, complete spreading was first observed after $5 \mathrm{~h}$.

When CM was replaced by CMS $24 \mathrm{~h}$ after cell seeding, proliferation of HEC was observed $2 \mathrm{~d}$ after cell seeding on the positively-charged MMA, and $4 \mathrm{~d}$ after cell seeding on the 85 HEMA/15 TMAEMA-Cl and 85 MMA 15 MMA copolymers. 

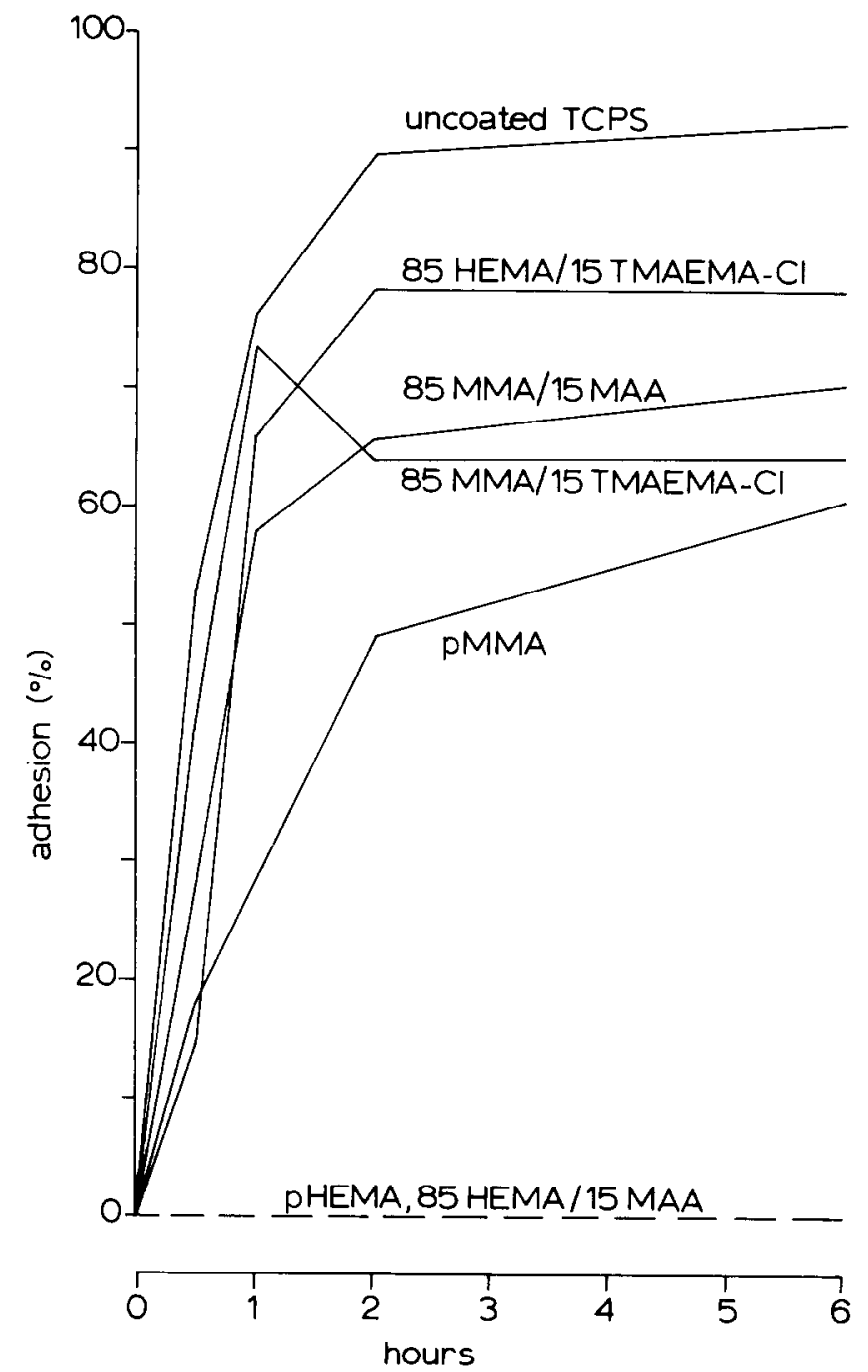

Figure 2 Adhesion of HEC onto (charged) methacrylate (co)polymers and TCPS as a function of time: $4 \times 10^{4} \mathrm{cells} / \mathrm{cm}^{2}$ in CMS were seeded anto the test surfaces. Cell counts at $30 \mathrm{~min}, 1,2$ and $6 \mathrm{~h}$ are expressed as percentages of numbers of cells adhering to TCPS precoated with Fn ${ }^{c}$. For abbreviations, see Materials and Methods.

Table 3 Adhesion of HEC after 1 h onto methacrylate (co)polymers and TCPS*

\begin{tabular}{llll}
\hline (Co)polymer & Series a & Series b & Series c \\
\hline PHEMA & 0 & 0 & 0 \\
75 HEMA 25 MMA & $6.6 \pm 5.5$ & ND & 0 \\
50 HEMA 50 MMA & $29.8 \pm 14.8$ & ND & 0 \\
25 HEMA 75 MMA & $47.4 \pm 7.6$ & ND & 0 \\
PMMA & $41.4 \pm 7.0$ & ND & 0 \\
85 HEMA 15 MAA & ND & 0 & 0 \\
85 HEMA 15 TMAEMA-Cl & ND & $65.8 \pm 18.8$ & $58.0 \pm 3.1$ \\
85 MMA 15 MAA & ND & $58.2 \pm 17.7$ & $8.6 \pm 2.9$ \\
85 MMAN15 TMAEMA-Cl & ND & $73.4 \pm 1.6$ & $52.8 \pm 3.1$ \\
TCPS & $91.7 \pm 8.4$ & $76.4 \pm 2.7$ & $49.6 \pm 3.8$ \\
\hline
\end{tabular}

* $4 \times 10^{4}$ cells $/ \mathrm{cm}^{2}$ were seeded onto the test surfaces in the presence of CMS (series $a$ and b) or in the presence of CM (series c). Cell counts are expressed as percentages of numbers of cells adhering to TCPS precoated wtih $\mathrm{Fn}^{\mathrm{C}}$. For abbreviations, see Materials and Methods.

ND, Not determined.

\section{DISCUSSION}

Adhesion and proliferation of different types of mammalian cells onto polymers is influenced by polymer surface characteristics like (water) wettability and charge ${ }^{1,2}$. In the series of HEMA $/$ MMA (co)polymers the highest number of adhering $\mathrm{HEC}$ and the most extensive spreading of $\mathrm{HEC}$ were found on the moderately wettable copolymer $25 \mathrm{HEMA} / 75 \mathrm{MMA}$ (contact angle of $39^{\circ}$ ), using CMS as the culture medium. Less HEC adhered onto more hydrophilic or more hydrophobic (co)polymers, whereas no adherent HEC were observed on PHEMA. This is in agreement with the lack of the ability of a variety of other cell types to adhere onto this material ${ }^{4-6,22,23}$. In a previous study ${ }^{4}$, we also observed that optimal adhesion of HEC in the presence of serum occurs onto moderately wettable materials (contact angle of $\pm 40^{\circ}$ ).

Because the adhesion experiments mentioned above (series a) were carried out in CMS, adsorption of serum proteins onto the surfaces may have influenced the adhesion of HEC. Both the composition of the adsorbed protein layer and the conformation of proteins at the surfaces may be important. Fibronectin ( $\mathrm{Fn})$, present in serum, is known to promote cell adhesion ${ }^{1}$. Apart from $\mathrm{Fn}$, the adsorption of other serum proteins, such as vitronectin, may influence cell adhesion $^{24-26}$. Preferential adsorption and/or optimal conformation of cell adhesion promoting proteins at the surface, such as Fn, could be the reason for the high numbers of adhering and spreading HEC on(to) the 25 HEMA 75 MMA copolymer. This hypothesis is supported by the work of others. Horbett et al. ${ }^{4}$ found maximal spreading of $3 T 3$ cells and maximal adsorption of Fn on the 50/50 copolymer of ethyl methacrylate (EMA) and HEMA as compared to (co)polymers of other compositions in this EMA/HEMA copolymer series. Grinnell and co-workers suggested that on TCPS, increase of fibroblast spreading occurs concommitantly with increase of $\mathrm{Fn}$ adsorption ${ }^{27}$. This behaviour was not observed on hydrophobic polystyrene (PS). It was also suggested that $\mathrm{Fn}$ is biologically more active on TCPS than on PS ${ }^{28,29}$. Previously, we compared the protein adsorption from CMS onto TCPS with the adsorption onto hydrophobic surfaces ${ }^{8}$. Fn was only detected on TCPS and not on hydrophobic fluorinated ethylene propylene copolymer. The lack of adhesion of HEC onto PHEMA is in agreement with the low and reversible protein adsorption usually observed on hydrophilic surfaces ${ }^{30}$.

Proteins released by cells during adhesion and spreading may be adsorbed onto the surfaces of the substrate. It has been shown that Fn secreted by fibroblasts mediates initial adhesion in serum-free medium ${ }^{31}$. Fn is also synthesized by endothelial cells ${ }^{32}$ and is present in the extracellular matrix ${ }^{33}$. Two other proteins produced by endothelial cells, i.e. von Willebrand factor and thrombospondin, may also be involved in adhesion and/or spreading of the cells $\mathrm{s}^{33,34}$. Desorption of adsorbed serum proteins from the polymer surfaces and exchange with adhesive protein(s) deposited by the cells is likely to be taking place and may occur preferentially upon moderately wettable polymers ${ }^{8}$.

In the absence of serum, HEC did not adhere onto HEMA/MMA copolymers (series $\mathrm{c}$ ), indicating that protein adsorption from serum is essential for the initial HEC adhesion onto these materials. Moreover, the results indicated that cellular adhesive protein deposition may not, or may insufficiently, occur from cells in suspension. The lack of HEC adhesion onto HEMA MMMA (co)polymers in CM contrasts with bacterial cell adhesion onto these surfaces in serum-free medium ${ }^{11}$. Maximal adhesion of bacteria (Staphylococcus epidermidis) occurs onto PMMA, while the adhesion onto the more hydrophilic surfaces is considerably reduced.

In the presence of serum, HEC adhere onto the negatively-and positively-charged MMA copolymers (85 MMA 15 MAA and 85 MMA 15 TMAEMA-Cl) and the positively- 
charged HEMA copolymer (85 HEMA/15 TMAEMA-Cl) (series $b$ ). In order to detach the cells from the positivelycharged surfaces, incubation with a concentrated trypsin solution was required. This indicates that a strong electrostatic interaction between the negatively-charged cell membrane and the positively-charged surface occurs. The adhesion of HEC onto the negatively-charged MMA copolymer may be partly ascribed to interactions between the cell surface and proteins adsorbed onto hydrophic domains of the polymer surface. Protein adsorption onto the negatively-charged HEMA copolymer, lacking hydrophobic domains at the surface, is supposed to be slight and reversible and no cell adhesion was found to occur onto this surface. Our results are in agreement with those of Hattori et $a / .^{6}$ who found maximal adhesion of fibroblasts upon positively-charged HEMA copolymers, whereas no adhesion was observed upon negatively-charged HEMA copolymers.

The number of cells adhering onto copolymers of HEMA or MMA and MAA or TMAEMA-Cl is reduced when HEC are seeded in serum-free medium (series c; Table 3). In particular, the adhesion onto the negatively-charged MMA copolymer after $1 \mathrm{~h}$ is dramatically reduced, confirming the assumption that serum proteins adsorbed onto this material are involved in HEC adhesion. However, the number of adhering cells increased in time as confirmed by light microscopy (not shown). Apparently, the rate of adhesion onto the negatively-charged MMA copolymer is substantially lower when compared to the adhesion rate on the positivelycharged copolymers, due to a high potential energy barrier for adhesion in the former case.

In the absence of serum, HEC adhere very strongly onto the positively-charged surfaces, because detachment by trypsin was not possible. It is interesting that in the absence of serum complete cell spreading occurred upon the positively-charged MMA copolymer. Complete spreading of HEC in the absence of serum upon surfaces, which had not been preadsorbed with cell adhesive protein, has not been observed previously. In this case, cell spreading may be facilitated by electrostatic interactions. Bacteria in serumfree medium also show maximal adherence onto positivelycharged HEMA or MMA copolymers, whereas the adhesion onto a negatively-charged MMA copolymer was somewhat reduced. No bacteria adhered onto the negatively-charged HEMA copolymer ${ }^{11}$

\section{CONCLUSIONS}

This study demonstrates that in the presence of serum the highest number of adhering HEC is found on a moderately wettable copolymer of HEMA and MMA. Furthermore, HEC adhere onto copolymers containing positivelycharged monomers. Copolymers containing negativelycharged monomers only show HEC adhesion when the second monomer has a hydrophobic character. In the absence of serum, adhesion of HEC onto these charged copolymers still occurs but is somewhat reduced. Under these conditions complete spreading of HEC was oniy observed upon the positively-charged copolymers.

\section{REFERENCES}

Grinnell, F., Cellular adhesiveness and extracellular substrates, Int. Rev. Cytol. 1978, 53, 65

2 Baier, R.E., Adhesion: mechanisms that assist or impede it, Science $1968,168,1360$
3 Coleman, D.L., Gregonis, D.E. and Andrade, J.D., Blood-materials interactions: the minimum interfacial energy and the optimum polar/ apolar ratio hypothesis, J. Biomed. Mater. Res. 1982, 16, 381398

4 Horbett, T.A., Schway, M.B. and Ratner, B.D., Hydrophilic-hydrophobic copolymers as cell substrates: effect on $3 T 3$ cell growth rates, J. Col. Interface Sci. 1985, 104, 28-39

5 Lydon, M.J., Minett, T.W. and Tighe, B.J., Cellular interactions with synthetic polymer surfaces in culture, Biomaterials 1985, 6, 396402

6 Hattori, S., Andrade, J.D., Hibbs, J.B., Gregonis, D.E. and King, R.N., Fibroblast cell proliferation on charged hydroxyethyl methacrylate copolymers, J. Col. Interface Sci. 1985, 104, 72-78

7 van Wachem, P.B., Beugeling, T., Feijen, J. Bantjes, A. Detmers, J.P. and van Aken, W.G., Interaction of cultured human endothelial cells with polymeric surfaces of different wettabilities, Biomateria/s 1985 , 6. 403-408

8 van Wachem, P.B., Vreriks, C.M., Beugeling, T., Feijen, J., Bantjes, A., Detmers, J.P. and van Aken, W.G., The influence of protein adsorption on interactions of cultured human endothelial cells with polymers, J. Biomed. Mater. Res. (submitted)

9 Grinnell, F. and Field, M.K., Initial adhesion of human fibroblasts in serum-free medium: possible role of secreted fibronectin, Ce/l 1979 , 17, 117

10 Hogt, A.H., Gregonis, D.E., Andrade, J.D., Kim, S.W., Dankert, J. and Feijen, J., Adhesion of coagulase-negative Staphylococci onto polymers and copolymers, J. Col. Interface Sci. 1985, 106, 289

11 Hogt, A.H., Gregonis, D.E., Andrade, J.D., Kim, S.W., Dankert, J. and Feijen, J., Adhesion of coagulase-negative staphylococci onto methacrylate polymers and copolymers, \&. Biomed. Mater. Res. 1986, 20(4), 533

12 Gregonis, D.E., Chen, C.M. and Andrade, J.D., in Hydroge/s for Medical and Related Applications, (Ed. J.L. Andrade), ASC Symp. Series No. 31. Amer. Chem. Soc. Washington D.C., 1976

13 Gregonis, D.E., Russell, G.A., Andrade, J.D. and De Visser. A.C. Polymer 1978, 19, 1279

14 Hattori, S., Preparation, characterization and cell growth of selected hydrophilic methacrylates, PhD Thesis, Department of Matcrials Science and Engineering, University of Utah, Salt Lake City, 1980

15 Coleman, D.L., In vitro blood materials interactions: a multi test approach, PhD Thesis, Department of Pharmaceutics, University of Utah, Salt Lake City, 1980

16 Andrade, J.D., King, R.N., Gregonis, D.E. and Coleman, D.L., J. Polymer Sci. Symp. C. 1979, 66, 313

17 Gregonis, D.E., Hsu, R., Buerger, D.E., Smith, L.M. and Andrade, J.D., in Solvent-property Relationships in Polymers (Eds R.B. Seymour and G.A. Stahl), Pergamon Press, New York, 1982, p 120

18 Adamson. A.W., Physical Chemistry of Surfaces (3rd Edn), WileyInterscience. New York, 1976

19 van Wagenen, R.A., Coleman, D.L., King, R.N., Triolo, P., Brostrom, L. Smith, L.M., Gregonis, D.E., and Andrade, J.D. Streaming potential investigations: polymer thin films, J. Col. Interface Sci. 1981, 84, 155

20 Jaffe, E.A., Nachman, R.L., Becker, C.G. and Minick, C.R., Culture of human endothelial cells derived irom umbilical veins. Identification by morphologic and immunologic criteria, J. Clin. Invest. 1973, 52. 2745

21 Willems, Ch., Astaldi, G.C.B., de Groot Ph.G., Janssen, M.C., Gonsalves, M.D., Zeijlemaker, W.P., van Mourik, J.A. and van Aken, W.G. Media conditioned by cultured vascular smooth muscle cells, Exp. Cell. Res. $1982,139,191$

22 Faris, B., Mozzicato, P., Mogayzal, P.J., Ferrera, R., Gerstenfeld, L.C., Glembourtt, M., Makarski, J.S., Haudenschild, C.C. and Franzblau, C., Effect of protein-hydroxyethyl methacrylate hydrogels on cultured endothelial cells, Exp. Cell. Res. 1983, 143, 15

23 Folkman, J. and Moscona, A., Role of cell shape in growth control, Nature 1978, 273, 345

24 Knox, P. and Griffiths, S., The distribution of cell-spreading activities in sera: a quantitive approach, J. Cell Sci. 1980, 46, 97

25 Knox, P. and Griffiths, S., The abnormal morphology of polyomatransformed baby hamster kidney cells is due to a failure to respond to 70K spreading factor, J. Cell Sci. 1982, 55, 301

26 Ruoslahti, E., Pierschbacher, M.C., Suzuki, S., Pytela, R., III, C.R. and Hayman, E.G., Serum adhesive proteins: molecular anatomy of the cell adhesion-promoting activity of fibronectin and related adhesion proteins, $X^{\text {th }}$ Internat. Cong. Thrombosis and Haemostasis, San Diego, CA, USA, July 14-19, 1985, Abstract 326

27 Grinnell, F. and Field, M.K., Fibronectin adsorption on hydrophilic and hydruphobic surfaces detected by antibody binding and analysed during cell adhesion in serum-containing medium, J. Biol. Chem. 1982, 257(9), 4888-4893 
28 Grinnell, F. and Feld, M.K., Adsorption characteristics of plasma fibronectin in relationship to biological activity, J. Biomed. Mater. Res. $1981,15,363-381$

29 Grinnell, F., The role of fibronectin in the bioreactivity of material surfaces, in Biocompatible Polymers, Metals and Composites (Ed. M. Szycher), Technomic Publ. Co., Lancaster, PA, USA, 1983, pp 673699

30 Feijen, J., Beugeling. T., Bantjes, A. and Smit Sibenga, C.Th. Biomaterials and interfacial phenomena, Adv. Phys. 1979, 3, 100

31 Grinnell, F. and Feld, M.K., Initial adhesion of human fibroblasts in serum-free medium: possible role of secreted fibronectin, Cel/ 1979
17, 117-129

32 Jaffe, E.A. and Mosher, D.F., Synthesis of fibronectin by cultured endothelial cells, J. Exp. Med. 1978, 147, 1779-1791

33 Reinders, J.H., de Groot, Ph., Dawes, J., Hunter, N.R., van Heugten, H.A.A. Zandbergen, J. Gonsalves, M.D and van Mourik, J.A. Comparison of secretion and subcellular localization of von Willebrand factor with that of thrombospondin and fibronectin in cultured vascular endothelial cells, Biochim. Biophys. Acta 1985, 844, 306-313

34 Mosher, D.F., Doyle, M.J. and Jaffe, E.A., Synthesis and secretion of thrombospondin by cultured human endothelial cells, J. Biol. Chem. $1982,93,343$ 